\title{
Artists as beholders: drawings after sculptures as a medium and source for the experience of art
}

Raphael Rosenberg

An array of evidence suggests that in Florence in the mid-sixteenth century the experience of art began to be understood as an exercise which required and promoted a greater attentiveness to the visual properties of the work, as well as a greater sensitivity on the part of the beholder to the perceptual and conceptual processes involved. ${ }^{1}$ When we try to gain deeper insight into the nature of this experience, however, the limitations of the written sources leave us at something of a loss: we have a significant number of documents from the early seventeenth century informing us of the role of the viewer, but only relatively few have come down to us from the Cinquecento.

In view of this situation, the purpose of this chapter is to draw attention to a non-verbal source that current research has so far neglected: drawings made from works of art. My aim is to establish the importance of drawn copies as means of documenting the ways in which sixteenth-century artists experienced art. I would further argue that such drawings in fact offer a better, more articulate indication of such experiences than the remaining writings, owing to the fact that the description and analysis of art was still a relatively undeveloped literary genre. In what follows I hope to show that the close scrutiny of such copies can significantly broaden and deepen our knowledge of the way art was perceived. My thoughts were developed on the basis of a comprehensive study of copies and written descriptions of the sculptures of Michelangelo, ${ }^{2}$ but here I will concentrate on the New Sacristy of San Lorenzo in Florence, a work of special interest in the sixteenth century and thus of particular value in charting the reception of art during that period. Long before the Chapel was finished and finally used as a mausoleum, it attracted visitors rather like a museum, above all artists, who came to see and study Michelangelo's works. 


\section{The New Sacristy between mausoleum and museum}

The New Sacristy was commissioned by the two Medici Popes Leo $X$ and Clement VII as the burial place for the last legitimate members of their family. It is located in symmetrical relation to the old Medicean sepulchral site of the church of S. Lorenzo, Brunelleschi's Old Sacristy, and from the very beginning it is referred to as the New Sacristy (sagrestia nuova). ${ }^{3}$

From 1519 onwards, Michelangelo was responsible for the architecture and sculptural decoration of the tombs. At the death of Clement in September 1534, the work was temporarily interrupted. The project was then well advanced: the architecture of the whole structure, including cupola and lantern as well as both ducal tombs, was finished, but only two statues - those of Giuliano, Duke of Nemours and Lorenzo, Duke of Urbino - had already been set up. The allegories of the four Times of Day were still lying on the ground; the tomb for Lorenzo the Magnificent and his brother Giuliano was not yet built; Michelangelo's unfinished Madonna and Montelupo's St Damian were in a nearby workshop; Montorsoli's St Cosmas was not yet completed. After the descendants of Cosimo the Elder and Lorenzo the Magnificent had become extinct in 1537, Cosimo I, the son of Giovanni delle Bande Nere, a descendant of the brother of Cosimo the Elder, seized power and became the founder of the dynasty of Medici grand dukes. These Medici were distant relatives of those who were buried in the Sacristy, a fact that might explain why the completion of the tombs - requiring relatively little work - took another quarter of a century.

The comparative lack of interest on the part of the reigning dukes in bringing the work in the Chapel to its completion stands in marked contrast to the interest shown by the Florentine artists, as well as the ordinary citizens and many foreign visitors who were always looking for a chance to get into the Chapel. As long as Michelangelo was working in the Sacristy, it seems to have been very difficult for any outsider to view it. Vasari succeeded in gaining access in 1532-33, thanks to the offices of Ottaviano de' Medici and only because Michelangelo was away. ${ }^{\dagger}$ After work in the Sacristy was abandoned and Michelangelo left Florence for good in September 1534, it gradually became easier to get in: around 1535 Tribolo made a present of his terracotta copy of Night to Figiovanni, the prior of S. Lorenzo, to thank him for having given access, ${ }^{5}$ and already in 1536 several artists - according to Vasari, 'all Florentine sculptors and painters' - seem to have been regularly making studies in the Chapel. ${ }^{6}$

The Sacristy was open to the public - probably for the very first time - on 15 March 1537, during the burial ceremonies for Duke Alessandro, interred in the sarcophagus of his supposed father Lorenzo, Duke of Urbino.? Access to the Sacristy became quite easy from around 1540 
onwards. In 1543 Anton Francesco Doni tells us of several visits and in his description of the monuments and artistic sites of Florence he awards the Sacristy a special status. By the end of 1546, Pier Francesco Riccio, Cosimo's majordomo, managed to take control of the key to the Sacristy away from the priests, whom he regarded as ignorant and insensitive in artistic matters, and had the place cleaned of dust and cobwebs. ${ }^{8}$ Yet the work in the Chapel was only finished in 1561, when the statues for the tomb of the magnifici brothers Giuliano and Lorenzo were set up. After that the daily and nightly masses with the continuous intercession for the souls of the dead could begin. The liturgical functions were probably restricted to the choir and did not prevent viewers from looking at Michelangelo's works. The door was now permanently open and access to the Chapel was no longer an issue. For the French traveller Nicolas Audebert, who gives a detailed description of the monuments and of the masses during his visit in 1576, the Chapel is 'the most beautiful thing in Florence' ${ }^{9}{ }^{9}$ Chronicles, travel diaries, and letters indicate that hundreds of people went to the New Sacristy - not to pay homage to the Medici but to admire Michelangelo's works. Artists were especially eager to study his sculptures. Altogether I have been able to trace about sixty drawings by thirty different artists of the Cinquecento after Michelangelo's sculptures, either actually executed in the Chapel, or copies based on such drawings, and this number does not include the sheets which were made after terracotta, wax or bronze reductions. No other ensemble by Michelangelo attracted so many artists in the sixteenth century. A comparable number of drawings after statues in the Renaissance period was produced, if at all, only after antiquities. These drawings confirm Vasari's reiterated accounts of artists coming to make their studies in the Chapel, and explain why he called it 'the school of our arts'. ${ }^{10}$ The number of surviving drawings also exceeds by far the number of drawings after the same sculptures made during the following centuries. ${ }^{11}$

Two drawings by Federico Zuccaro in the Louvre give an impression of what the Chapel looked like in the years 1560 or 1570 (Figures 5.1 and 5.2): ${ }^{12}$ A dozen artists are looking at the statues, drawing or modelling after them. Some of them sit in the middle of the Chapel, and because they would probably spend some time there, they have also brought food along. At the edge, where both drawings overlap, we notice the same young man who has climbed above one of Cosini's trophies and is resting his foot on the lower part of the lateral volute of the door lintel. The repetition of this figure is evidence of the accuracy of Zuccaro's snap shot-like scene. We in fact have a Florentine drawing of the second half of the sixteenth century in the University Library of Warsaw, which shows Michelangelo's Darm exactly as it is seen from that very point of view. ${ }^{13}$ 


\section{Three drawings after the Medici Madonna}

In order to give an idea of the variety found among these drawings, I have chosen three examples which were drawn after the Medici Madonna. Their illustrations are juxtaposed with photographs of the statue itself, taken from the same angle as the drawings.

The oldest known sheet after the Madonna is a pen drawing by Raffaello da Montelupo in the Louvre (Figures 5.3a and 5.3b), probably done while he was sculpting the St Damian for the New Sacristy in 1533-34, and thus prior to Michelangelo's abandonment of work. ${ }^{14}$ The sheet is used from top to bottom edge to inscribe the seated figure of the Madonna and Child. The attention of the draughtsman is focused, however, on the drapery in the middle. Montelupo devotes great care to the folds; he wants to grasp their volumes and to let us feel the relation between the underlying body and the dress. The proportions of the Madonna are elongated, the busy centre of the figure is unified by a calm outline. Montelupo's drawing looks like the side-view of an ancient sculpture: everything appears parallel to the surface of the paper, and the draughtsman elaborates that surface with his pen almost as if to create a finely chiselled relief. All forms and potential movements have been straightened so as to stress the perpendicular and horizontal directions. For example, the heads of the Madonna and of the Child, the body of the Child, and the long fold under his bottom, all form one straight, perpendicular axis, which is resumed on the right by the almost parallel lower leg of the Virgin and on the left by her right, supporting arm. Equally emphasized are all the horizontal folds and contours, which run parallel or are made parallel to the pedestal on which the mother is seated. These adjustments show no real regard for the emotional relationship between Mother and Child.

Ludovico Cigoli made a black chalk drawing of the same statue, probably in the 1580 s (Figures 5.4a and 5.4b). ${ }^{15}$ Except for the fact that shortly after 1559 the Madonna had been placed on the tomb of the magnifici and that Cigoli saw it therefore from below, the point of view is similar to Montelupo's. Cigoli's Madonna is also elongated and the irregularities of the overall contour are smoothed down. But unlike Montelupo, who clarifies and increases the strong tectonic and static aspects of the sculpture, Cigoli grasps its dynamic aspects. A mutual motion of contraction and extension, like bracket and spring, holds the group together. The mother is inclined to the right - note the treatment of the shoulder and the leg - and the child reaches up, stretching himself in a more exaggerated, yet natural torsion from top to toe. Note especially how his toes are pointed toward the viewer, his leg is lowered, his right shoulder is pushed higher, and his right arm is raised. The group fills the sheet; its energy seems to push against the edges all around. 
A red chalk drawing of the same statue was made by Andrea Boscoli (Figures 5.5a and 5.5b), ${ }^{16}$ who like Cigoli was a pupil of Santi di Tito. Unlike the two artists whose drawings have just been discussed, however, Boscoli chose the narrow view of the sculpture. Still, he must have slightly shifted his viewpoint while making the drawing, since more than one photograph is required to duplicate it. He cautiously completed details of the unfinished statue as can be seen especially in the foot of the mother and in the cloth under the leg of the boy. And whereas Michelangelo had left the glance of the Madonna's eyes undefined, Boscoli drew her eyelids lower, to give us the sense that she is looking down at her child, and so subtly reinforces their emotional relation. Besides this, Boscoli crisply develops the axes of the composition and intensifies their obliqueness. Mary's leg is much elongated; its upward direction to the right is prolonged by the knee of the boy, which is brought into one line with hers. At the same time, Boscoli counters this axis with a diagonal that starts with the boy's left foot and, passing over his knee, reaches Mary's right shoulder at the upper left. In this axis Boscoli connects the peaks of the superimposed forms of Mother and Child; step by step their recession leads the eye backward and toward the upper left. These two axes, in turn, form a large obtuse angle. They are further emphasized by Boscoli's use of chiaroscuro. The left side and the recessed space at the lower right are cast into shadow; the brightly-lit part on the right is set off by shading in the background. The bright light unifies the group along the angle formed by the two axes and resolves the statue into a serpentine line continued up to the Virgin's head. The group's contour on the left drops in a more or less straight, perpendicular line faithful to the appearance of the sculpture. The obliqueness of the contour on the right, however, is much more emphatic in the drawing, largely as a result of a sharp line in the shadow at bottom right. The entire group is thus inscribed into a tall triangle, rising from the base to an acute angle at the top. Boscoli places the group without its base into the middle of the sheet, as if floating in space.

The differences between these three drawings are considerable. They describe the same statue, yet vary their model in form and content in quite remarkable ways. What is the reason for these different approaches? What can we deduce from them?

A drawing after a sculpture is a translation from one medium into another. Because of the difference in media, only selected aspects of the sculpture can be rendered. As Gombrich has shown in Art and Illusion, any draughtsman is subject to a number of conventions, the totality of which we traditionally call style. The process of drawing after sculptures can therefore be described as a (re)constitution of specific aspects of the statue that makes use of acquired conventions. More than replication it is an active interpretation, based partly 
on style and partly on the specific function of the drawing. The interpretation involved is not confined to subject-matter, but extends to all aspects of a work. What roles do style and function play in this process?

\section{The style of the drawings}

We have seen that each of these drawings tended to alter what it was copying. Are such deflections and variations a function of the individual style of the draughtsman? In other words, could the artists have ever had the intention of drawing the Medici Madonna much differently than they did? For Raffaello da Montelupo we are in the lucky position to actually demonstrate that the answer is yes. On the verso of the Louvre drawing we find, surrounded by some hasty sketches, another drawing of the Medici Madonna, this time seen from the opposite side (Figures 5.6a and 5.6b). Here Montelupo has chosen to give a rather precise lateral view of the marble block. The artist's preference for the profile view is characteristic of his early oeuvre as a draughtsman; it may be explained as an attempt to avoid the difficulties of foreshortening. $\mathrm{He}$ is even capable of extreme twists in order to keep figures parallel to the surface of the sheet, as a drawing of Jupiter Kissing Ganymede in Oxford exemplifies (Figure 5.7). ${ }^{17}$ The drawing indicates that - despite his youth and his tendency to organize forms into shapes parallel to the surface - he can also conceive and represent on paper two figures in a dramatic action and with strong movements. Yet, it is the verso of the sheet in the Louvre which proves the point most clearly. There the Medici Madonna is studied in a much more lively manner than on the recto. Full of tender affection, the Mother is watching her Child, who coils around on her lap as he reaches for her breast. Montelupo stresses the line of the cloth in which the boy is wrapped. Falling down from below the Virgin's hand it reaches over the baby's left thigh and ties the two figures together more closely than in the statue. The verso of the Louvre drawing shows that the treatment of the statue on the recto - where all movement is frozen onto a flat surface - is not a necessary consequence of personal style. An artist might vary his approach in accordance with different intentions, at times emphasizing, in restrained linear discipline, the peaceful, tectonic quality of the sculpture, and at others, with a much looser and more lively line, its lively, playful, expressive qualities.

Neither from Cigoli's nor from Boscoli's hand do we have more than one drawing after the Medici Madonna. However, if we look through their work as draughtsmen, affinities to the sheets already discussed become apparent. Figures in vigorous motion are a hallmark of Cigoli, ${ }^{18}$ whereas Boscoli generally draws slightly elongated, often weightless and graceful figures; the articulation of diagonal axes is not a constant feature of his style. ${ }^{19}$ 
Because the style of a draughtsman establishes the delimiting conditions within which he carries out a specific interpretation when he makes a copy after a sculpture, his interpretation will share some features of his other works. Every style will miss out altogether on some aspects of the copied sculpture and within its limits each style will allow for different interpretations of the same model, as we have seen in the case of Raffaello da Montelupo.

\section{The function of drawings after statues}

The motives for making drawn copies in the Renaissance were study, reproduction, and interpretation. The practice of making drawings after sculpture in order to improve one's skill at drawing was already advocated by Alberti in $1435,{ }^{20}$ and many of the sheets executed in the Medici Chapel were done for this purpose. The artists were eager to study Michelangelo's figures because they were considered to be among the most perfect models available. The Chapel was a unique place, where one could find statues recumbent and seated, nude and draped, male and female, all made by the divine master. Many sheets with studies of details, like feet, hands and heads of the sculptures by Naldini and Morandini, attest to the interest in anatomical knowledge. ${ }^{21}$ Raffaello da Montelupo studies the folds of drapery and the rendering of the volume of the body beneath them on the recto of his sheet in the Louvre (Figure 5.3a).

Montelupo intended to produce at the same time a record of the sculpture by his master. This is demonstrated by the care taken to give an idea of the entire sculpture. He intended to reproduce the Medici Madonna at a time when no printed images were available. Explicitly reproductive drawings can be distinguished from study drawings by the fact that they render the entire sculpture and are more carefully executed, as can be seen in several sheets by Franco, Salviati, and Naldini which were then used for prints. Such drawings might also serve as models which the artists could incorporate in their own paintings or sculptures. ${ }^{22}$

At first glance, Boscoli seems to offer a reproduction, too (Figure 5.5a), though, as we have seen, he sometimes deliberately departs from his model. How decisively he has turned his back on the aim of giving a reproduction can be seen particularly in his shading: in order to achieve the intended effect, he changes the light in the Sacristy, which - from winter to summer, from morning to evening - is always virtually invariable. Yet when Raffaello da Montelupo exercises his capabilities as a draughtsman and, at the same time, tries to reproduce Michelangelo's figure, he, too, interprets it in a specific way.

Though Boscoli's emphasis in the pursuit of his aim is unusual in the sixteenth century, it proves that copies could be far more than either exercises 
made as part of an artist's training or simple reproductions. The two abovementioned drawings by Federico Zuccaro provide us with a rare insight into the circumstances that encourage a more interpretative approach to making copies. It has so far been overlooked that the two sheets each illustrate distinct stages in the reception of art. In the first drawing (Figure 5.1), all the figures are busy looking at and drawing or modelling the sculptures. In the second (Figure 5.2), the same people seem to be discussing their copies. On the left, three men are engaged in a conversation about a drawing. On the right, one man with a tall hat looks over the shoulder of a bearded artist who is still at work. The two sheets do not represent the familiar scenario of an artist's training, as in an academy, where senior artists correct the work of their juniors. Instead, we witness how individuals of equal standing share their ideas and compare the ways in which they each reproduced the sculpture. The drawings after statues have become objects of discourse. Copies are an element of the new culture of the Cinquecento which begins to look at and think about art more self-consciously.

We should remember that the visual arts or, more precisely the arti del disegno - since the former term was not coined until the eighteenth century - became a subject of public discussion among educated non-artists in Italy at about the same time. The subject of art was addressed in letters, often intended for a wider educated public even if addressed to a particular individual. Such letters - such as those of Pietro Aretino and Anton Francesco Doni - might be published in several editions during the lifetimes of their authors. Conversations about art, as shown in Zuccaro's drawing, were probably common in certain circles, especially in places such as Michelangelo's Chapel. Books in which the traditional form of the dialogue was adapted to the discussion of art provide further evidence for pre-existent patterns of discourse. From Paolo Pino's Dialogo di Pittura (1548) to Lodovico Dolce's Aretino (1557), to Raffaello Borghini's Il Riposo (1584), a large number of treatises on art of the sixteenth century were composed as dialogues.

\section{Descriptions versus drawings}

The origins of the modern description of art lie in the Cinquecento ${ }^{23}$ and Vasari is one of its pioneers. In the first edition of his Vite (1550) he was also the first to describe the Medici Madonna:

One is Our Lady, who is in a sitting attitude, with the right leg crossed over the left and one knee placed upon the other, and the Child, with the thighs astride the leg that is uppermost, turns in a most beautiful attitude towards His Mother, hungry for her milk, and she, while holding Him with one hand and supporting herself with the other, bends forward to give it 
to Him; and although the figure is not equal in every part, and it was left rough and showing the marks of the gradine, yet with all its imperfections there may be recognized in it the full perfection of the work. ${ }^{24}$

Vasari describes the action of the child wanting to be nursed and of the mother bending to fulfil this desire: like Cigoli and Boscoli (Figures 5.4a and 5.5a) he stresses the relation and movement of both figures toward each other. It is remarkable, on the other hand, that his text consistently follows the group from the bottom to the top and thus dares to begin the description of the Blessed Virgin with her leg. In doing so he shares with Boscoli (Figure 5.5a) the sensation of the overall upward movement. Unlike most descriptions in Vasari's Vite, which give hardly more than a general account of the narrative, these lines reproduce a rather detailed image of Michelangelo's figure, so precise that we can rightly doubt whether he mistook the left leg for the right one. Yet compared with the descriptions of the Medici Madonna in more recent art-historical literature, Vasari's text remains brief; his description leaves out many aspects which have found room in newer texts. These include the dress, the unusual composition compared to other statues of the Madonna and Child, the relation between the marble block and the various possible views, and the relation of the statue to the planned architectural setting and to the neighbouring sculptures. A certain restraint is also evident on the linguistic level: Vasari eschews metaphors, abundant in later descriptions, for instance. The conceptual vocabulary available to describe works of art was still rather limited. Many terms and expressions now commonplace were not yet in use. A good example is geometrical modes of analyzing pictures, virtually absent in sixteenth-century descriptions of art, despite the fact that geometry was a discipline familiar to the painters of the Renaissance. ${ }^{25}$ Describing the Medici Madonna from the bottom to the top, Vasari verbalizes an effect that we would nowadays express in geometrical terms, but that he could not have put more directly.

Writers of the twentieth century find it much easier to describe ideas such as 'overall upward movement'. In 1948 Charles de Tolnay wrote: 'The Virgin is seated on a narrow, high block, with one leg across and hiding the other, which rests on the ground, producing an effect of hovering. ${ }^{26}$ More dramatic is Anny Popp's distinctively expressionistic text of 1922, from which I quote only a few lines. The upward movement and the diagonals are described in a a way that is reminiscent of Boscoli's drawing (Figure 5.5a):

The Madonna is built up of nothing but opposing diagonals that hold each other in check: the diagonal of the leg crossing over and projecting from the depth with the incisive sharpness of a thin edge; the counter-slant of the Child's head and body; and, resuming the first diagonal in a milder mood, the inclined head of the Virgin. [...] Like a flash of lightning, these zigzagging lines are meant to cut through the architecture $[\ldots]$ with the thrust of their upward pull to the left and the right." ${ }^{27}$ 
Describing a statue is - just like drawing after it - a translation from one medium into another. Because of the differences in these media, it is possible to translate only some aspects of the statue and any translation will also depend on the author's or artist's intellectual preparation. ${ }^{28}$ Any description of a sculpture - just like a drawing after it - is always also an interpretation of it. Comparisons between such interpretations are appropriate and revealing: Boscoli's drawing after Michelangelo's Madonna (Figure 5.5a) and Vasari's description of the same group are two outstanding examples of their kind and perfectly suited to comparison. What Vasari indirectly articulated through the sequence of his text was expressed by Boscoli very clearly on his sheet. The fact that Boscoli obtained a more incisive and articulate result can be explained in terms of the different evolution of the media they are using. The literary conventions available in the sixteenth century for describing sculpture were much more limited than the expressive possibilities of drawing. Almost every artist made drawings after sculptures even if only during his training, but only a few sixteenth-century authors left written descriptions of works of art.

This diagnosis may be surprising to us; today we witness the opposite situation. Drawings have largely lost their importance. As means of reproduction they have been replaced first by printmaking and later by photography; in their function as exercises for young artists, they have been increasingly marginalized in the twentieth century. On the other hand, there are some modern artists who used drawing as a medium of interpretation and went on drawing after the Old Masters even when they got old; they include Paul Cézanne, Oskar Kokoschka, and Alberto Giacometti. In contrast, written descriptions and analyses of works of art have become ever more numerous and extensive. The genre has appropriated concepts and developed strategies which were entirely alien to Vasari.

\section{Conclusion}

The endowment for continuous intercession on behalf of the dead Medici princes founded by Pope Clement VII in 1532 in the New Sacristy is unique in Italy during the fifteenth and sixteenth centuries. ${ }^{29}$ Dynastic reasons might account for the fact that the masses commenced only after a delay of thirty years, but that the Chapel could turn into a space in which art was admired and studied independently of its religious context is symptomatic of the way in which the visual arts had come to be regarded by the sixteenth century. The Popes Leo X and Clement VII were perfectly aware of the artistic importance of the project when they commissioned Michelangelo to design and execute it. Yet they neither intended nor could foresee that, long before their intentions were realized, Michelangelo's sculptures would become the objects of 
contemplation as works of art. Many came because they were attracted by the name and fame of Michelangelo, and, for those beholders - I dare say, not unlike today's tourists - the identity of the individuals buried here and the iconographic programme were never the focus of their interest.

The history of the New Sacristy demonstrates that as early as the middle of the sixteenth century, there was a culture of serious engagement with works of art in Florence, shared by artists and non-artists; they included the infinite persone among the citizenry who came to inspect the still unfinished site during the obsequies for Duke Alessandro in 1537,,$^{30}$ as well as educated foreigners (Accademici Peregrini). ${ }^{31}$ By the end of the century, this growing interest found expression in the work of writers such as Francesco Bocchi, who, in his Bellezze della citta di Fiorenza (1591), devoted more than twenty pages to a detailed discussion of the Chapel..$^{32}$

While verbal strategies adequate to the discussion of sculpture were just beginning to be developed, drawn copies played an important part in transmitting more subtle and complex aspects of visual experience. These copies are revealing sources that enable us to understand the widely divergent ways in which Renaissance viewers responded to art.

Translation by Lutz Riester

\section{Notes}

1. Fumaroli 1994 argues that the modern spectator of art makes his appearance at the beginning of the seventeenth century in Rome, but he also points to the Florentine origins of the phenomenon in the mid-sixteenth century.

2. Rosenberg 2000.

3. See the detailed chronology of the history of the Chapel, with sources, in Rosenberg 2000, pp. $127-45$.

4. Vasari $1966 \mathrm{ff}$, VI, p. 372.

5. Vasari 1966 ff., V, p. 205.

6. '[...] le statue di Michelagnolo che sono nella Sagrestia nuova di San Lorenzo, dove allora essendo volti a disegnare e fare di rilievo tutti i scultori e pittori di Firenze [...]. Dimorando dunque Battista [Franco] in fra gli altri e frequentando la detta Sagrestia, fece amicizia con Bartolomeo Amannati scultore, che in compagnia di molti altri là studiavano le cose del Buonarroto'; Vasari 1966 ff., V, pp. 460-61. Vasari might be exaggerating, but his testimony is contirmed by seven drawings by Battista Franco after Day, Night and Dow'n; see Rosenberg 2000, NZ $193-9$.

7. El giovedi mattina in deto Santo Lorenzo si fece messe assai per il detto morto Duca, e tennono aperto la sagrestia nuova, in nella quale entro infinite persone per vederla.' Ridolfi 1958, p. 560.

8. E sarà cosa molto laudabile secondo l'instituto di Vostra Excellentia con questo peró se li piacera che le chiave di quel luogo non stiano in mano di quei preti: perche non se ne delectino, et io me navveggo, che à questi di per mano d'un chericacio è pericolato quel cristo di marmo si bello, [...] la suplicavo delle chiave sopra dette, cosi della libreria, e banchi della quale si son dati a fare al Tasso: et ci fara piacere, cosi sandrà rassestando tulti doi questi luoghi da ragnateli e dalla polvere che n'hanno dibisogno, accertandola che tutto 
Firenze sila] allegrata di questo fatto come degno di Vostra Excellentia. [Marginal note:] Le chiave tenetele voi fino si mette insieme quelle cose voi dite sono lavorate'; letter to Cosimo of 31 December 1546, Florence, Archivio di Stato, Mediceo 613, F. 55, No. 2, fols 71v-72r.

9. 'La plus belle chose de Florence', in 'Voyage d'Italie', MS., British Library, London, Lansdowne 720, fol. 189r.

10. '[...] la sagrestia dj San Lorenzo [...] lè] stato, e [è] et sara, fin che durerann gli annj, la scuola delle nostre arti'; letter to Cosimo of 16 February 1563, in Frey 1923, 1, p. 719. Vasari's letter must be read with his own interests in mind. He wanted to win the Duke's agreement to grant the newly-founded Accademia del Disegno some rooms in the monastery of S. Lorenzo and hoped he might commission the members of the Accademia to complete the Chapel's decoration; of. Waźbiński 1983, pp. 60-66 and Waźbiński 1987, I, pp. 83-95.

11. See the chart in Rosenberg 2000, p. 254. However, one has to bear in mind on the one hand that the survey is based mostly on museum collections and, on the other, that their sixteenth-century holdings are usually catalogued more systematically and completely than those of more recent periods.

12. Paris, Musée du Louvre, Département des Arts Graphiques, Inv. 4554, 198 $\times 262 \mathrm{~mm}$ and Inv. 4555, $187 \times 264 \mathrm{~mm}$, both black and red chalk.

13. Warsaw, Gabinet Rycin Biblioteki Universyteckiej, Coll. Royal, T. 173 no. $117 \mathrm{v}$, illustrated in Rosenberg 2000 , pl. 15 . The head of a young man on the recto is very similar to drawings by $\mathrm{F}$. Zuccaro.

14. Paris, Musée du Louvre, Département des Arts Graphiques, Inv. $715 r$, pen and brown ink, wash, $367 \times 249 \mathrm{~mm}$.

15. Firenze, Uffizi, $1232 \mathrm{Er}$, black chalk, $270 \times 170 \mathrm{~mm}$. The drawing still bears a nineteenth-century attribution to Raffaello da Montelupo. The reasons for its new attribution to Cigoli are discussed in Rosenberg 2000, pp. 217-18. The dating of this study rests on the account of Cigoli's nephew and biographer, Giovanni Battista Cigoli, who says that the artist had made a number of studies in the New Sacristy towards the end of the 1580s; see Baldinucci 1974-75, VII, p. 43.

16. Whereabouts unknown, red chalk, $288 \times 213 \mathrm{~mm}$.

17. Oxford, Ashmolean Museum, P. 407, pen and brown ink, over red chalk, $252 \times 181 \mathrm{~mm}$; see Parker 1956, pp. 204 5; Berenson 1935/36, p. 115, fig. 20. Three-quarter views of seated figures would, correspondingly, seem to be of a later date. Despite Berenson's systematic study, the chronology of Montelupo's drawings has not yet been established.

18. For a survey of Cigoli's drawings, see Chappel 1992.

19. E.g. Forlani 1959, fig. 1 (Uffizi 464 F), 17 (Istituto Nazionale per la Grafica Inv. 130610) and 20 (Uffizi 8249 F). See also Forlani 1963. A so far unpublished catalogue of Boscoli's drawings has been drawn up by Julian Brooks (Ashmolean Museum, Oxford).

20. Meder 1923 , p. 264.

21. Rosenberg 2000, NZ 321-5, and 327-35.

22. See Rosenberg 2003. On the general phenomenon of quoting figures of other artists, see Irle 1997.

23. For a survey of the genre, see Rosenberg 1995. On the sixteenth century, see Frangenberg 1990 and Frangenberg 1995. On the seventeenth century, see Rosenberg 1997. On ancient ekphrasis and its difference to the modern tradition of description, see Webb 1996 and Webb 1999.

24. 'L'una è la Nostra Donna, la quale nella sua attitudine sedendo manda la gamba ritta addosso alla manca con posar ginocchio sopra ginocchio, et il putto, inforcando le cosce in su quella che più alta, si storce con attitudine bellissima inverso la madre chiedendo il latte, et ella, con tenerlo con una mano e con l'altra appogiandosi, si piega per dargliene. Ancora che non siano finite le parti sue, si conosce, nell' esser rimasta abozzata e gradinata, nella imperfezzione della bozza la perfezzione dell'opra.' Vasari 1962, 1, pp. 60-61; English translation: Vasari 1912-15, IX, p. 45.

25. Geometric terms occur in some descriptions of paintings and sculptures of the seventeenth century, and are used in a more systematic manner after the middle of the eighteenth century; see Rosenberg 2004.

26. De Tolnay 1948, p. 71. 
27. '[Es] entstanden in der Madonna lauter Gegendiagonalen, die sich selbst das Gleichgewicht halten: Die schneidend scharf als schmale Kante aus der Tiefe herausspringende Diagonale des übergekreuzten Beines, die Gegenschräge des Kopfes und Rumpfes des Kindes und, wieder die erste Diagonale in milderem Nachklang anschlagend, der geneigte Kopf der Madonna. [...] Wie ein Blitz sollten diese Zickzackdiagonalen der Madonna durch die Architektur zucken [...] mit ihrem links und rechts aufwärtsweisenden Bewegungszug [...].' Popp 1922, p. 62. Comparable statements are found in Salvini 1977, p. 118: '[...] il fattore condizionante della verticalita della figura, contrastata soltanto, con efficacia, dalla lunga obliqua della gamba sinistra, accavalciata sull'altra che scompare nel masso, e dalla parallela sulla quale si dispongono in alto il collo e la testa'.

28. Baxandall 1991, p. 44, makes the point with sobering acuity: 'Any language [...] is a conspiracy against experience in the sense of being a collective attempt to simplify and arrange experience into manageable parcels. The language has a limited number of categories, grouping phenomena in its own way, and a very limited number of conventions for setting these categories in relation to each other.'

29. Ettlinger 1978, p. 295.

30. Ridolfi 1958. The Diario is clear on the fact that they came to look at the Chapel (vederla).

31. The title of one of the chapters of Doni's Marmi of 1552 is 'Academici Peregrini e Fiorentini e l'Aurora di Michel Agnolo Buonaruoti', see Doni 1928, pp. 20-24. The Accademici Peregrini are seen in the role of the foreigners who question the local traditions and request to be shown the Florentine monuments. In Venice there was an institution called the Accademia Pellegrina; Doni was a member of this society and, from 1553 to 1563, its secretary; see Longo 1992, p. 162.

32. Bocchi 1591, pp. 260-82. 


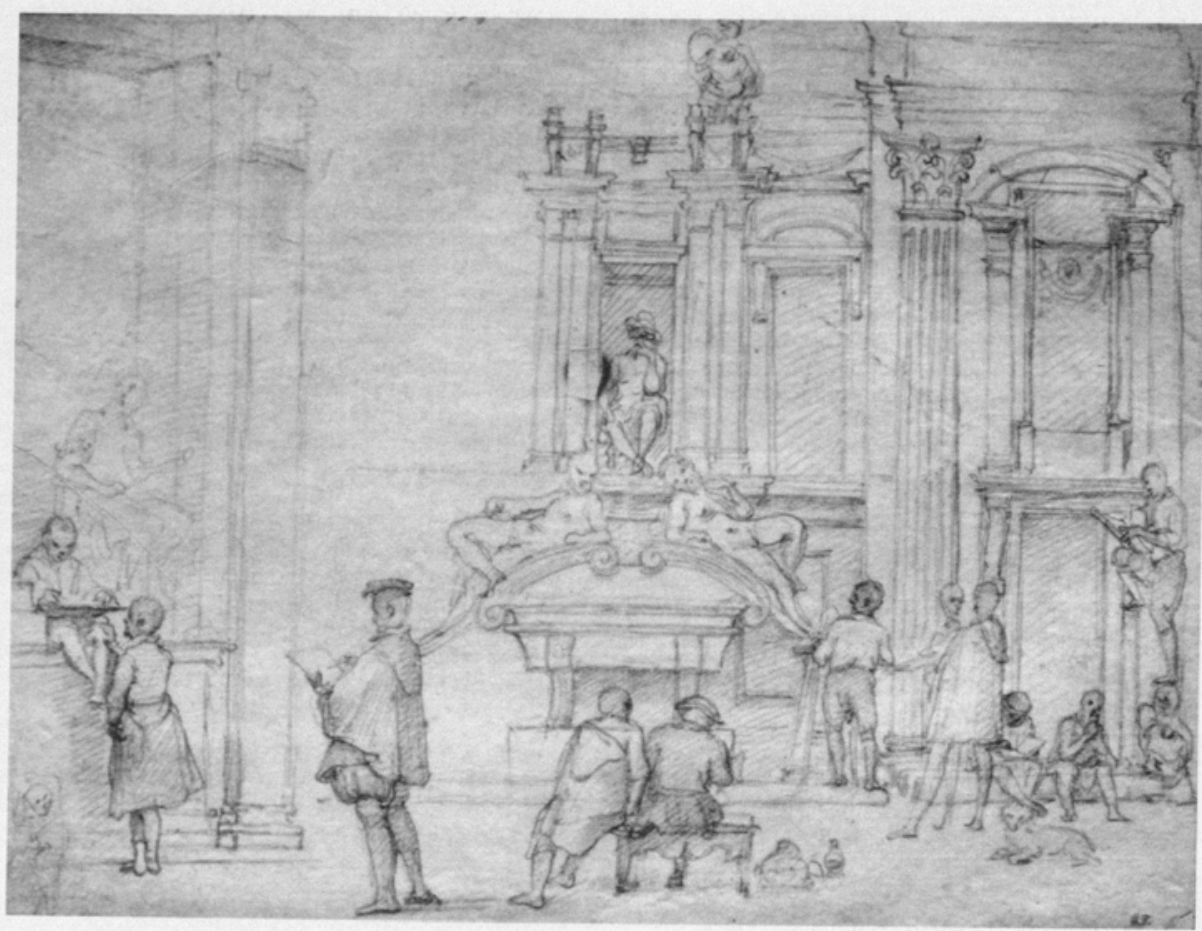

5.1 Federico Zuccaro, New Sacristy, Louvre, Inv. 4554 


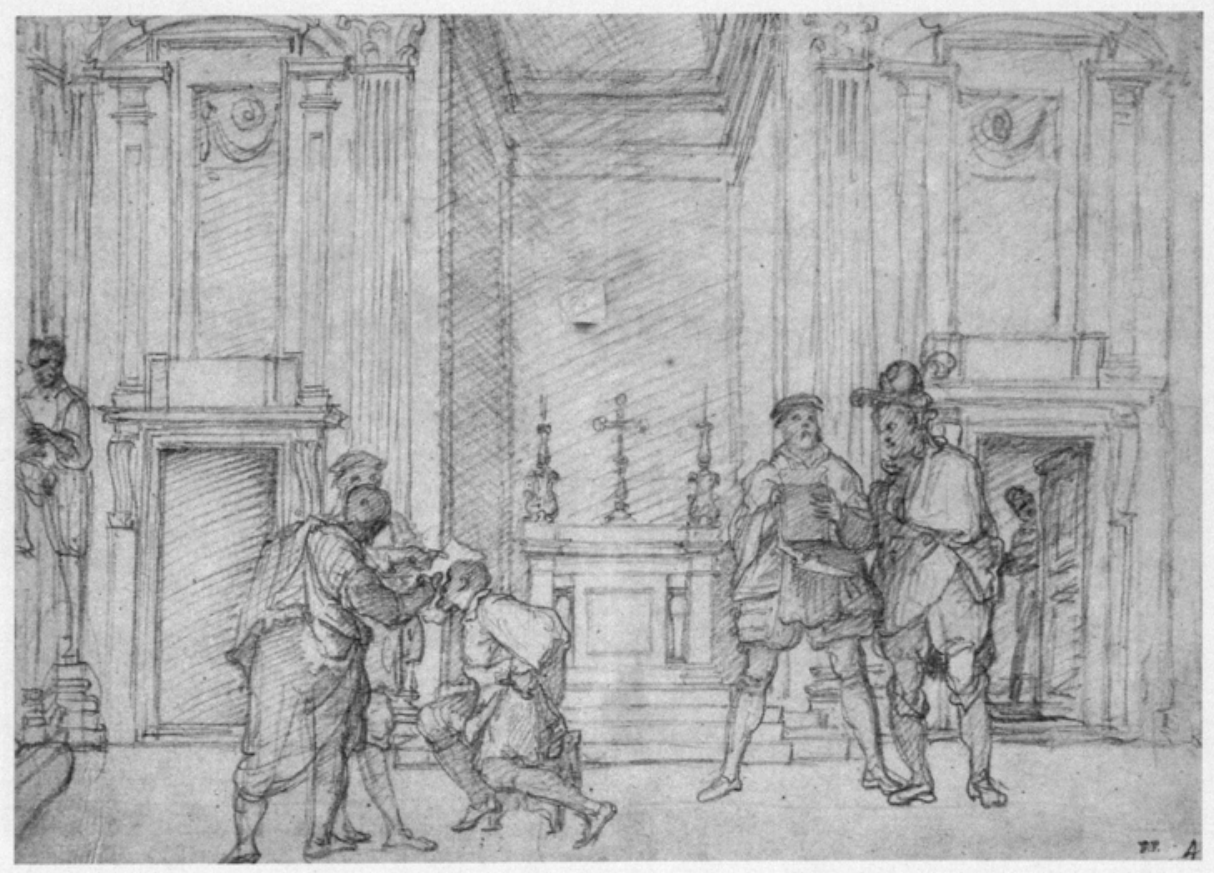

5.2 Federico Zuccaro, New Sacristy, Louvre, Inv. 4555 


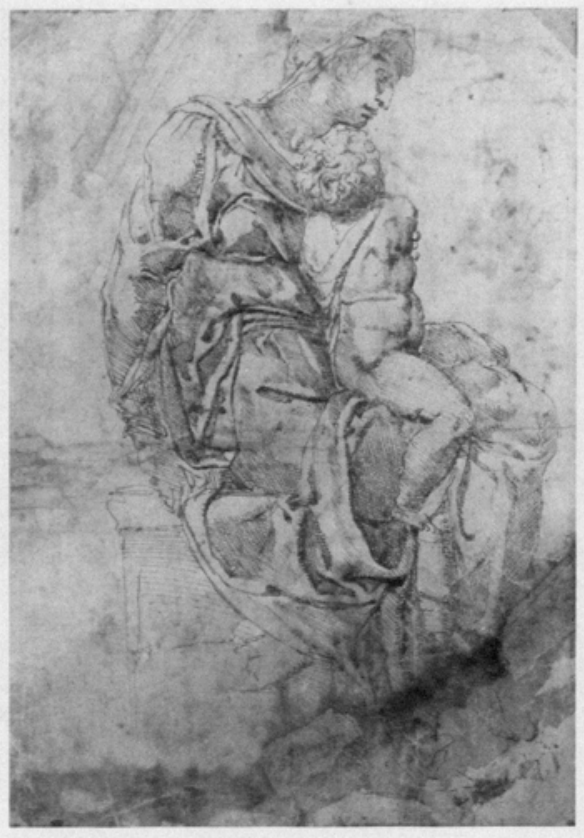

5.3a Raffaello da Montelupo, Medici Madonna, Paris, Louvre, Inv. $715 \mathrm{r}$

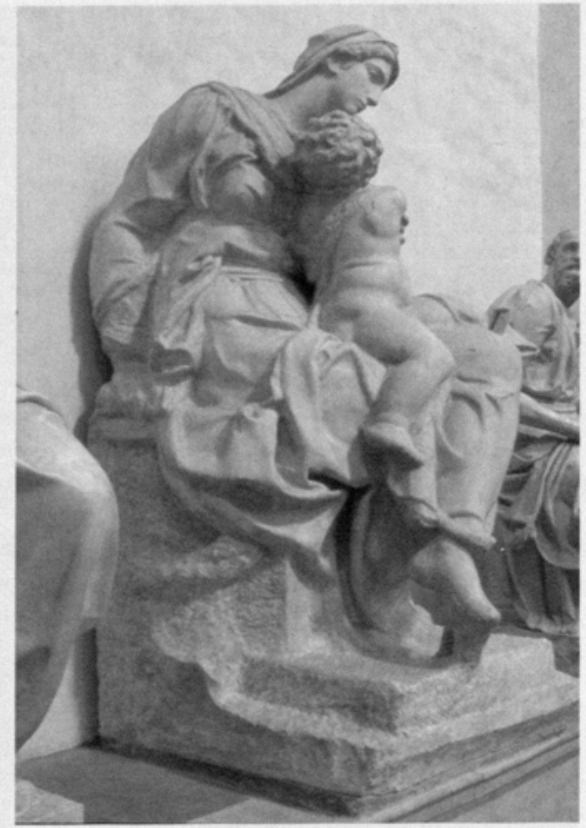

5.3b Michelangelo, Medici Madonna, New Sacristy, S. Lorenzo, Florence 


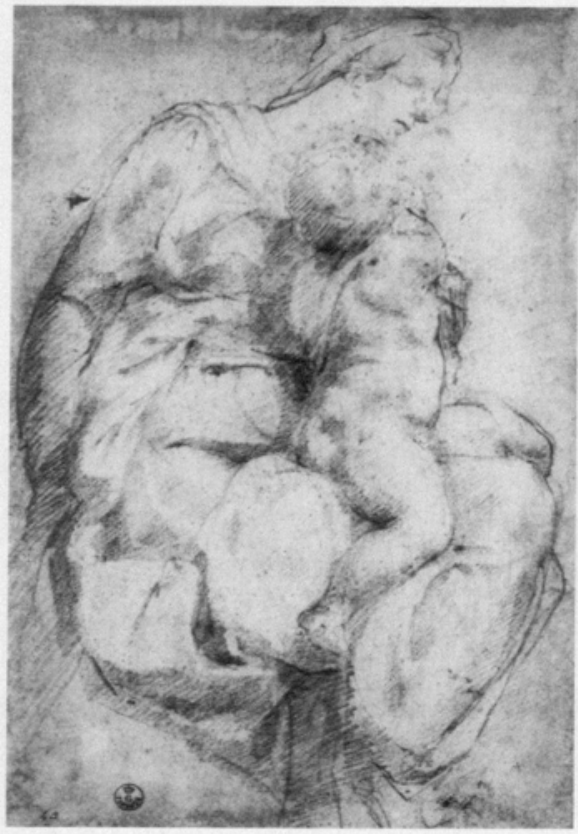

5.4a Ludovico Cigoli, Medici Madonna, Florence, Uffizi, E 1232 E r

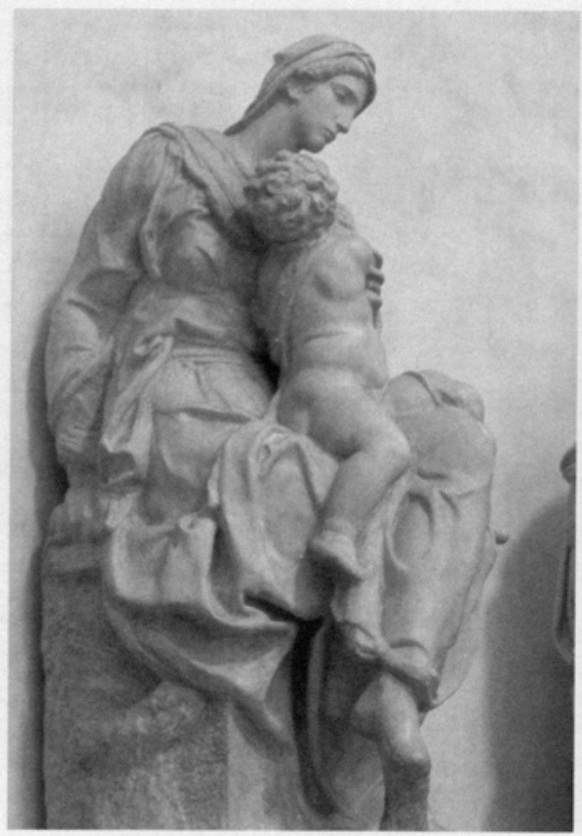

5.4b Michelangelo, Medici Madonna, New Sacristy, S. Lorenzo, Florence 


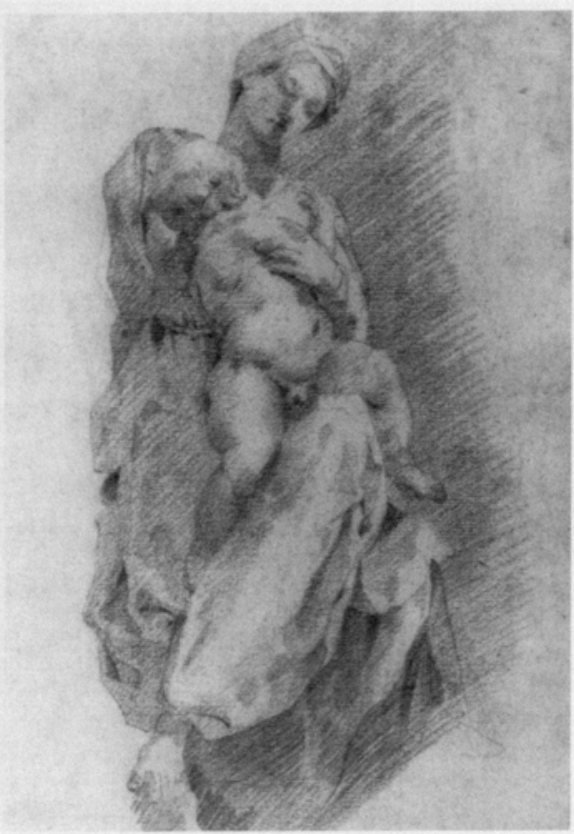

5.5a Andrea Boscoli, Medici Madonna, private collection

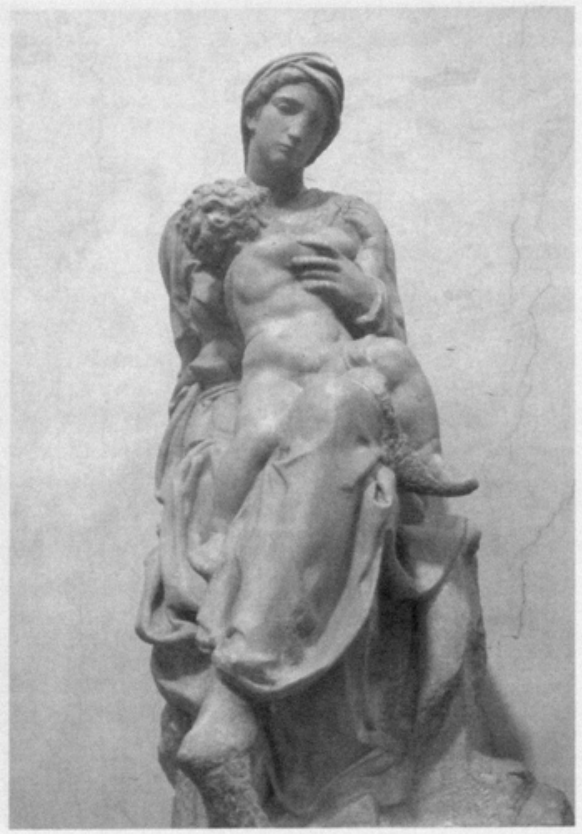

5.5b Michelangelo, Medici Madonna, New Sacristy, S. Lorenzo, Florence 


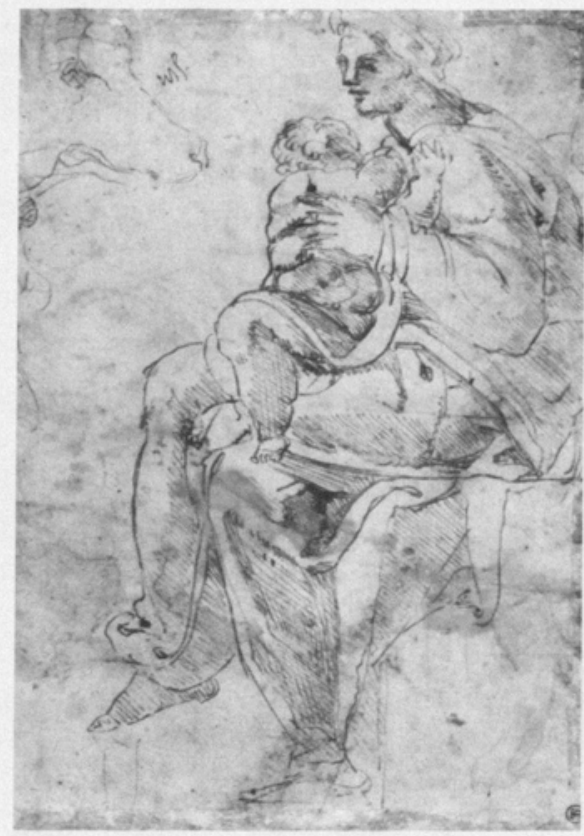

5.6a Raffaello da Montelupo, Medici Madonna, Paris, Louvre, Inv. 715 v, detail

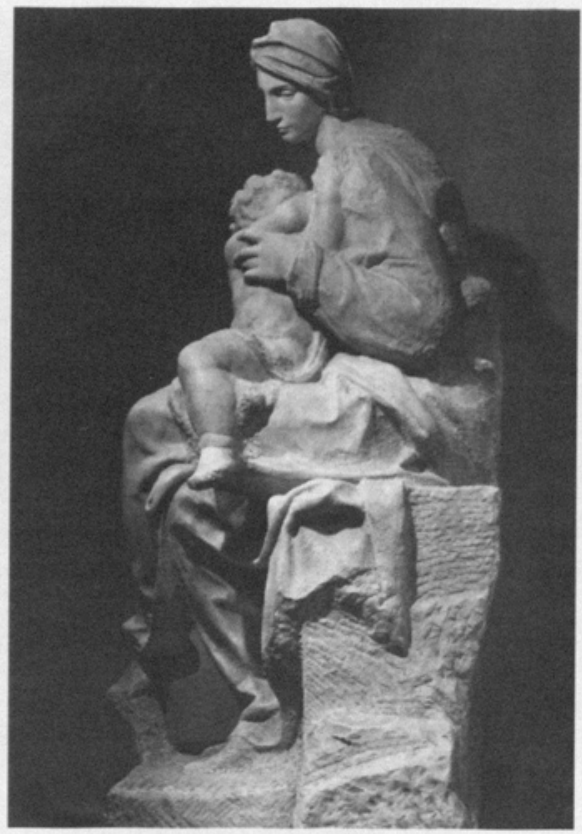

5.6b Michelangelo, Medici Madonna, New Sacristy, S. Lorenzo, Florence 


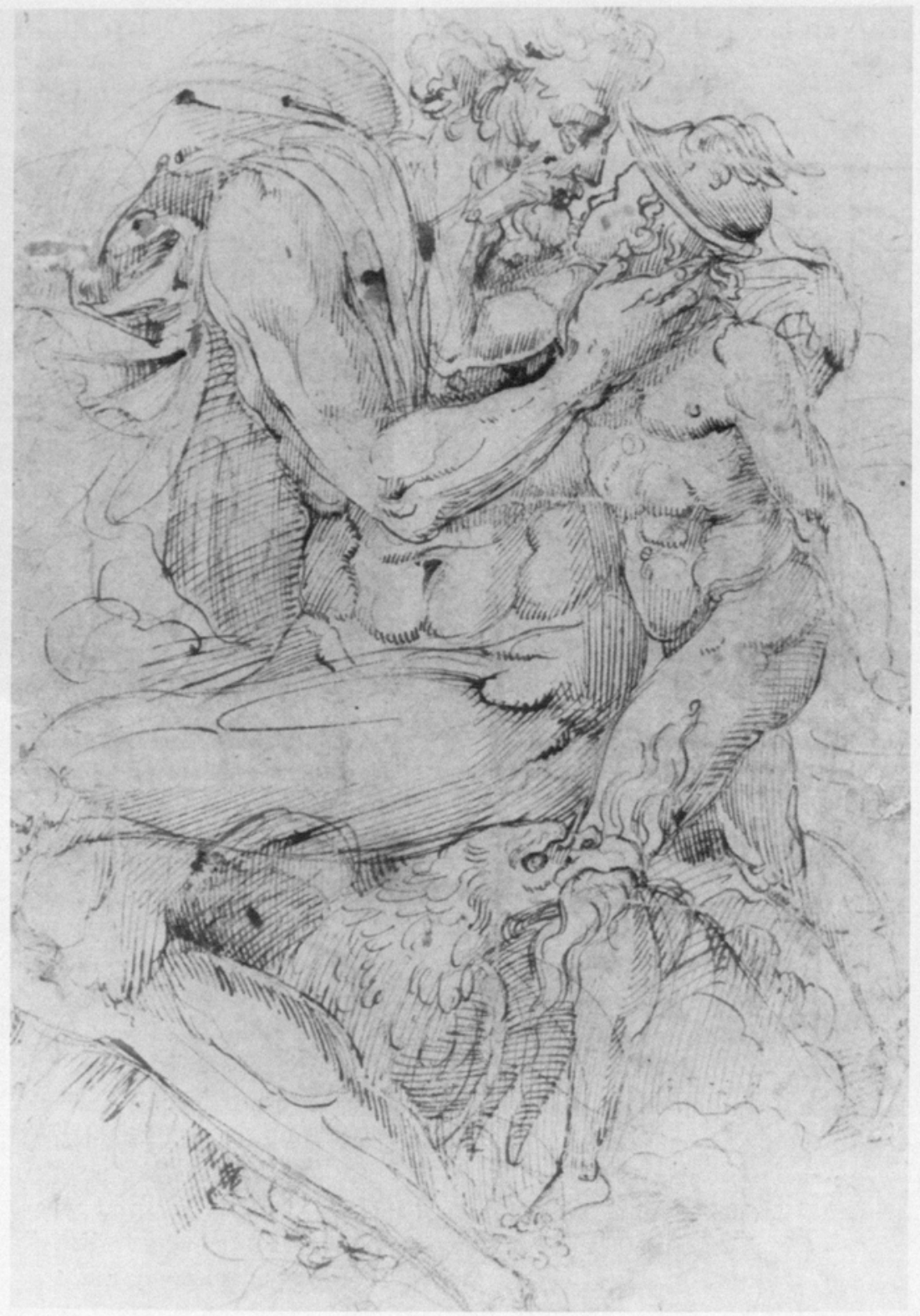

5.7 Raffaello da Montelupo, Jupiter Kissing Ganymede, Oxford, Ashmolean Museum, P. 407 